\title{
DEIXIS IN THE LEGEND OF LAKE TOBA STORY
}

\author{
Gina Lugina ${ }^{1}$, Eka Nuryulia $\mathbf{R}^{2}$, Dasep Suprijadi ${ }^{3}$ \\ ${ }^{1}$ IKIP Siliwangi \\ ${ }^{2}$ IKIP Siliwangi \\ ${ }^{3}$ IKIP Siliwangi \\ ${ }^{1}$ ginalugina43@gmail.com, ${ }^{2}$ Ekanur8020@gmail.com, ${ }^{3}$ suprijadi.dasep17@gmail.com
}

\begin{abstract}
Language is more than a sign as it can function as a tool for communication among humans. This means that language can be learned by the humans. One of the fields that study the language is pragmatics. Pragmatics can be defined as the study of contextual meaning; therefore there should be a relationship between language and the context. However, this relationship can be recognized through deixis. The purpose of this paper is to analyze the types of deixis found in the story of "The Legend of Lake Toba". This paper uses descriptive qualitative method, because it analyzes the types of deixis found in the story. The method of collecting the data is documentation. Specifically using theory of Alan Cruse (2000) about deixis. The steps to analyze the data are reading the story, finding the deixis, and classifying the types of deixis. The finding showed that the types of deixis like personal deixis, spatial deixis, and temporal deixis are used in The Legend of Lake Toba story. In this research, personal types is the dominant types that occur in this story.
\end{abstract}

Keywords: Deixis, Story, Pragmatics, The Legend of Lake Toba

\section{INTRODUCTION}

This research focuses on the study in The Legend of Lake Toba Story because it will be more interesting if we study about something which becomes too close to part of human life such as story. Basically, story could be said as a part of discourse. Moreover, the researcher assumes that many deixis words and also their meaning could be found in The Legend of Lake Toba Story. In this study, the researchers want to analyze the deixis in The Legend of Lake Toba Story, not only because it has deictic words but also many people in Indonesia have known about the story.

Deixis is the study of deictic or indexical expressions in language, like you, now, today. It can be regarded as a special kind of grammatical property instantiated in the familiar categories of person, tense, place and so on (Levinson, 2004). Fillmore (1975) said that dexis means showing something. Dexsis regarding the way in which context the language encoding of speach, in this case the interpretation of the utterence depends on the context of speach analysis and daixsis can be found in any language. Layons (cited in John, 1977) offers the following definition of deixsis: "the location and identification of persons, objects, events, processes and activities being talked about, or referred to, in relation to the spatiotemporal context created and sustained by the act of utterence and the participation in it, tipically of a single speaker and at least one addressee."

There are certain elements of the above epigraphs which pose problem regarding their interpretation. In the Vaughan extract, the pronouns you and I and the spatial adverb Here suggest not only the subjectivity of the utterer, but a shared domain with the reader or addressee. Our interpretation of the shop door note would depend on a knowledge when the note was 
written. Without this knowledge the recipient cannot tell whether he or she is likely to be waiting under a minute or nearly half an hour. What govern the interpretation of these utterences-and what causes the problems, is deixis. The linguistic phenomenon of deixis is a fundamental element of discourse. A Greek word meaning 'pointing', deixis has been adapted by linguists to refer to the encoding of the spatio-temporal context and the subjective experience of the encoder in an utterance. Initially used of a small body of words and expressions which link the encoder with the situation of utterance, deixis has been extended to cover a broad range of language fragments.

The short story has never actually achieved the status held by length fiction. Short story deals with important elements that build the story itself. All of these elements take their own role to make the story sensible. They are theme, plot, setting, character and point of view (Anderson, 1993, as cited in Hansyar: 2005).

As being above, short story is an art of literary genres, which is fiction. Short story can be categorized as a fiction since most of it relies on fantasy stories, such as fairy tale. It is further explained by Klarer (Mario, 1998) the roots of short story lie on antiquity and the Middle Ages story, myth and fairy tale relate to the oldest types of textual manifestations, "texts" which were primarily orally transmitted. Short story as a part of literary works is interesting to be analyzed. Although it has a quite short lot, small number of characters and a few places and time as setting, the story can be fully developed. There are many short stories that have been analyzed. Typically, the analysis is related to intrinsic elements of the story.

\section{METHOD}

This section discusses the method that the researchers used in this current research method which consist of research design, research participant and procedure. In this research the researchers use descriptive qualitative method. According to Fraenkel and Wallen (2008) cited in Apsari, Syatroh and San Rizqiya (2017), qualitative data is collected in the form of words or images, rather than numbers. It means that the research is based on the characteristics of phenomena and the data were analyzed using the description not number. The researchers elect short story of The Legend of Lake Toba Story. In collecting the data for the research, the researchers followed these steps. Firstly, the researchers searched the story of The Legend of Lake Toba on the internet. Secondly, the researchers read the story, one by one and two several times in order to understand the story in detail. Thirdly, the researchers chose the story to be analyzed (Khalili, 2017)

\section{RESULTS AND DISCUSSION}

\section{Results}

Table.1 Personal Deixis Found in The Legend of Lake Toba Story

\begin{tabular}{ll}
\hline \multicolumn{1}{c}{ Types of Person Deixis } & Number of Words \\
\hline I & 22 \\
\hline You & 22 \\
\hline They & 7 \\
\hline He & 75 \\
\hline She & 11 \\
\hline It & 8 \\
\hline Total & 145 \\
\hline
\end{tabular}


Table.2 Spatial Deixis Found in The Legend of Lake Toba Story

\begin{tabular}{ll}
\hline Types of Spatial Deixis & Number of Words \\
\hline There & 6 \\
\hline This & 15 \\
\hline That & 24 \\
\hline Total & 45 \\
\hline
\end{tabular}

Table.3 Temporal Deixis Found in The Legend of Lake Toba Story

\begin{tabular}{ll}
\hline Types of Temporal Deixis & Number of Words \\
\hline Once upon a time & 1 \\
\hline One day & 1 \\
\hline Tonight & 1 \\
\hline Now & 1 \\
\hline Total & 4 \\
\hline
\end{tabular}

Table.4 Deixis used in "The Legend of Lake Toba Story"

\begin{tabular}{ll}
\hline Types of Deixis & Number of Words \\
\hline Personal & 145 \\
\hline Spatial & 45 \\
\hline Temporal & 4 \\
\hline
\end{tabular}

\section{Discussion}

Based on the results of the research obtain above the researchers found personal dexis, spatial deixis, and temporal deixis taken from the short story "The Legend of Like Toba"

1. Personal Deixis

Below personal deixis taken from story, the researchers takes each type of personal deixis who adjusted in the example found in the theory, such as I, you, we, they, he, she, it.

\section{a. First Person Deixis}

When person in the story will turn the lamp on and feel scared when he sees a woman in his house. Following the sentence:

$$
\text { "Ooo....hhhiii.... Alright, I will turn the lamp on." }
$$

The word $I$ in the sentence above is the first person deixis, because it refers to someone who will do something.

\section{b. Second Person Deixis}

Second person deixis is found in the sentence about someone, using the first single person who is scolding his child and expressing frustration. Following the sentence:

“You are rebellios child. You are lazy, uselless!!!” Toba got angry.

The word you in the sentence above is the second person deixis, because it refers to his child. c. Third Person Deixis

Third person deixis, the writer of the story describes the unmarried Toba even though he was adult. Following the sentence: 
He decided being single and didn't get married, although his age was mature enough to a family.

The word he and his in the sentence above is the third person deixis because it refers to Toba.

\section{Spatial Deixis}

Below this is spatial deixis which is found randomly by the researchers and the data taken are limited and adjusted to the internal example theory.

a. Tobs who told him self about where he worked until night came. Following the sentence:

He liked fishing and he could do this activity until night has come.

The word this in the sentence above is spatial deixis, because this refers to the story of his life.

\section{Temporal Deixis}

Below this is temporal deixis which is found randomly by the researchers and the data taken are limited and adjusted to the internal example theory which explains about time.

A writer retells his life story in "The Legend of Lake Toba Story" he tells how his day is. Following the sentence:

One day, after worked on his small farm, he decided to go fishing.

The word one day in the sentence about is temporal deixis, because it refers to one day, the day the writer told it.

\section{CONCLUSION}

Following the discussion above, finally the researcher concludes that the story of The Legend of Lake Toba use all types of deixis which are personal deixis always occurs in every story. Personal deixis that is used includes three types of personal deictic word which are first person deixis, second person deixis and third person deixis (Mutmainah, 2014). In addition, the other types which are spatial deixis and temporal deixis also occur in the story. Therefore, the researcher notes that by using the deixis it will make easily to describe the function of personal, pronoun, time, demonstrative and lexical future which are connecting the utterance with relation of space and time and also useful to catch the reference meaning that include who, where and when the utterance is uttered (Hasanah, 2016).

\section{ACKNOWLEDGMENTS}

All praise may due to Allah SWT who always blesses me in every second of my life until I can finish this paper under the title "Deixis in The Legend of Lake Toba Story". Peace and salutation to Prophet Muhammad SAW who has guide us from the darkness to the lightness.

I realize that my paper will never finish without some contribution from many people who give advices and critiques in order to make betterment for this paper. Therefore, I would like to express my deepest gratitude to my parents, who give me support and never stop praying for me. Above all, I would like to thank to my lecturer, Dasep Suprijadi, M.Pd, for her advices and knowledge of doing research. 
Finally, I as the researcher expect and need more constructive criticism and suggestion from the readers to make this paper more perfect.

\section{REFERENCES}

Apsari, Y., Syathroh, I. L., \& San Rizqiya, R. (2017). Promoting English Teachers'professional Development (TPD) Through The Practice Of Lesson Study. OKARA: Jurnal Bahasa dan Sastra, 11(2), 303-318.

Hasanah, U. (2016). A Pragmatic Study on Deixis in The Song Lyrics of Harris J's "Salam" Album. Malang.

J, Fillmore, C. (1975). an alternative to checklist theories of meaning. Proceeding of the First Annual Meeting of the Berkeley Linguistics Society., 123-131.

John, L. (1977). Semantics. cambridge: Cambrige University Press.

Khalili, E. (2017). Deixis Analysis in A Tale of Two Cities written by Charles Dickens., 4(3), $58-65$.

Levinson. (2004). Pragmatics. London: Cambrige University Press.

Mario, K. (1998). An Introduction to Literary Studies. New York: Routledge.

Mutmainah. (2014). Pragmatic Study of Location and Social Deixsis Between English and Bugines Language. Hasanuddin University Makassar. 